\title{
Alterações Morfológicas de Bactérias Contaminantes de Hortaliças Minimamente Processadas em Inóculo Misto Induzidas por Carvacrol e 1,8-Cineol Isolados e em Combinação
}

\author{
Kataryne Árabe Rimá de Oliveira (I), José Alberto da Costa \\ Medeiros (I), Geany Targino de Souza (I), Jossana Pereira de \\ Sousa (II), Regina Célia Bressan Queiroz de Figueiredo (III), \\ Evandro Leite de Souza (I)
}

(I) UFPB - Universidade Federal da Paraíba (Cidade Universitária - João Pessoa - PB - Brasil - CEP: 58051-900), (II) UFPE - Universidade Federal de Pernambuco (Cidade Universitária Recife - PE - Brasil - CEP: 50670-901), (III) CPqAM - Centro de Pesquisas Aggeu Magalhães

(Campus da UFPE - Cidade Universitária - Recife - PE - Brasil - CEP: 50670-420)

\section{Resumo}

Hortaliças minimamente processadas (HMP) são consideradas alimentos saudáveis e naturais, mas que devido à sua intensa manipulação podem ser veículos para micro-organismos, com destaque para o grupo das bactérias psicrotróficas, as quais possuem capacidade de multiplicação em temperaturas de refrigeração. $\mathrm{O}$ risco do consumo deste tipo de alimento tem elevado a necessidade do desenvolvimento de novas práticas para controlar a sobrevivência e crescimento dessas bactérias. Óleos essenciais e compostos relacionados são considerados candidatos potenciais para aplicação em HMP, no sentido de garantir a segurança microbiológica do produto. O objetivo deste trabalho foi avaliar os efeitos dos compostos carvacrol (CAR) e/ou 1,8-cineol (CIN) sobre a morfologia de bactérias psicrotróficas contaminantes de HMP. Cepas tipo padrão (Listeria monocytogenes ATCC 7644, Pseudomonas fluorescens ATCC 11253, Aeromonas hydrophila INCQS 7966), em inóculo misto (1:1:1), foram expostas ao CAR e CIN em suas Concentrações Inibitórias Mínimas (CIM) (CAR: 1,25 $\mu \mathrm{l} / \mathrm{ml}$; CIN: $40 \mu \mathrm{l} / \mathrm{ml}$ ) e combinados em concentrações

\footnotetext{
Referência:

Kataryne Árabe Rimá de Oliveira, José Alberto da Costa Medeiros, Geany Targino de Souza, Jossana Pereira de Sousa, Regina Célia Bressan Queiroz de Figueiredo, Evandro Leite de Souza.Alterações Morfológicas de Bactérias Contaminantes de Hortaliças Minimamente Processadas em Inóculo Misto Induzidas por Carvacrol e 1,8-Cineol Isolados e em Combinação. In: Anais do 12 Congresso Latinoamericano de Microbiologia e Higiene de Alimentos - MICROAL 2014 [= Blucher Food Science Proceedings, num.1, vol.1]. São Paulo: Editora Blucher, 2014.

DOI 10.5151/foodsci-microal-301
} 
subinibitórias (CAR: 0,156 $\mu \mathrm{l} / \mathrm{ml}, \mathrm{CIN}: 5 \mu \mathrm{l} / \mathrm{ml}$ ). Em diferentes intervalos de tempo, alíquotas foram retiradas e submetidas ao preparo para visualização em Microscópio Eletrônico de Varredura (MEV) (1, 4 h), para observação da ocorrência de alterações ultraestruturais, e em Microscópio Confocal (15, $30 \mathrm{~min})$ para verificação de alterações na permeabilidade de membrana e viabilidade celular. As imagens da MEV mostraram alterações logo após $1 \mathrm{~h}$ de exposição, quando CAR e CIN foram ensaiados de forma isolada ou em combinação, apresentando células alongadas e distorcidas com superfícies rugosas, que diferiram das células controle cuja morfologia bacilar apresentava-se normal. As imagens da Microscopia Confocal mostraram que algumas células tratadas com os compostos isolados ou em combinação após 15 min apresentaram uma coloração intermediária (fluorescência amarelada) e após 30 min ocorreu mudança no perfil de fluorescência, do verde (células intactas) ao vermelho (células danificadas/mortas). As células não expostas aos compostos exibiram fluorescência verde brilhante. Todas estas alterações morfológicas observadas nas células bacterianas expostas ao CAR e ou CIN são indicativas de um aumento da permeabilidade e perda de integridade da membrana, o que pode conduzir à morte celular.

Palavras-Chave: Carvacrol, 1,8-cineol, Inóculo misto, Morfologia Agência de Fomento: Conselho Nacional de Desenvolvimento Científico e Tecnológico 